Review de Debut

ロジウム触媒によるプロパルギルエステルの
1 ,2-アシロキシ転位を経る新反応

酒井 一憲

\title{
New Reactions via 1,2-Acyloxy Rearrangement \\ of Propargylic Esters by Rhodium Catalysts
}

Kazunori Sakai

Propargylic esters are transformed into vinylcarbenoids via 1,2-rearrangement of acyloxy groups by transition metal catalysts. This review describes new reactions proceeding via the 1,2-acyloxy rearrangement using rhodium catalysts.

はじめに

プロパルギルエステルのアルキン部位が，遷移金属錯 体へ配位することにより求電子性が増加すると, エステ ル基の分子内求核攻撃を受ける。このとき，アルキン部 位のエステル基側の炭素上で求核攻撃が起こると，5員 環構造を有するビニルメタル種 A を経て 1,2-アシロキ シ転位が進行し，ビニルカルベノイド種 Bへ変換でき る $(\text { 式 } 1)^{1)}$ 。このようにして発生させたビニルカルベノ イド種 B は, シクロプロパン化, 芳香族炭素-水素結合 への挿入反応など様々な反応を起こすことが知られてお り, これまでに，パラジウム，白金，ルテニウム，金な どの触媒を用いた様々な反応例が報告されてきた ${ }^{2)}$ 。最 近，新たにロジウム錯体を触媒として用いた，プロパル ギルエステルの 1,2-アシロキシ転位を鍵とする不飽和化 合物との新反応が開発されたので，本稿にて紹介す る $^{3-5)}$ 。<smiles>[R]C=C(C=[18O])OC([R1])=O</smiles>

\section{1. 電子不足アルケン, アルキンとの反応}

プロパルギルエステルを用いたアルケンのシクロプロ パン化反応は数多く報告されているが，カルベノイド種 が求電子的であるため, 電子不足アルケンとの反応への 適用は困難であった。しかしながら, 2010 年, 田中ら はカチオン性のロジウム触媒を用いることで, アクリル アミド類のシクロプロパン化反応を達成した $(\text { 式 } 2)^{3)}$ 。

また，アクリルアミド類に代わってアセチレンカルボ ン酸エステルを用いると, ビニルカルベノイド種とアル キンの $[3+2]$ 環化付加により， シクロペンテン誘導体が 得られる(式 3 )。

\section{2. 一酸化炭素との反応}

2010 年, 福山, 柳, Fensterbank, Malacria らは, 一酸
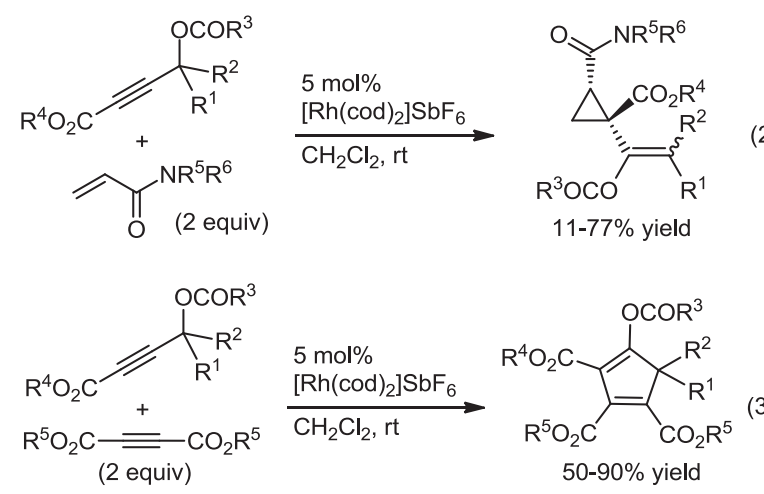

化炭素加圧下，3-アシロキシ-1,4-エンインをロジウム 触媒を用いて反応させると, $[5+1]$ 環化付加が進行し， レゾルシノール誘導体が得られることを報告している (式 4) ${ }^{4 a)}$ 。

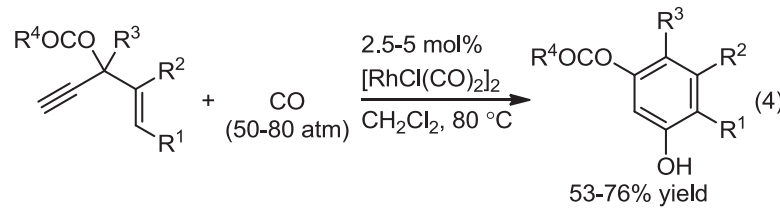

本反応に関して筆者らは，エステル基の 1,2-転位によ り発生したビニルカルベノイド種 C と一酸化炭素の反 応によってケテン D が生成し, $6 \pi$ 電子環状反応, 異性 化を経て進行するという機構を提唱している(スキーム 1)。

実際, 本反応を 20 当量のメタノールを添加して行っ た場合, 目的のレゾルシノール誘導体の他に，ケテン中 間体を捕捉して生成したと考えられるメチルエステルが 得られたことも，上記の反応機構を支持している(式 5)。

\section{3. アルキンとの反応}

2011 年に Tang らは, 3-アシロキシ-1,4-エンイン部 位以外にも，アルキンをもつ基質をカチオン性ロジウム 触媒存在下で反応させると, $[5+2]$ 分子内環化付加反応 が進行し，シクロヘプタトリエン誘導体が生成すること 


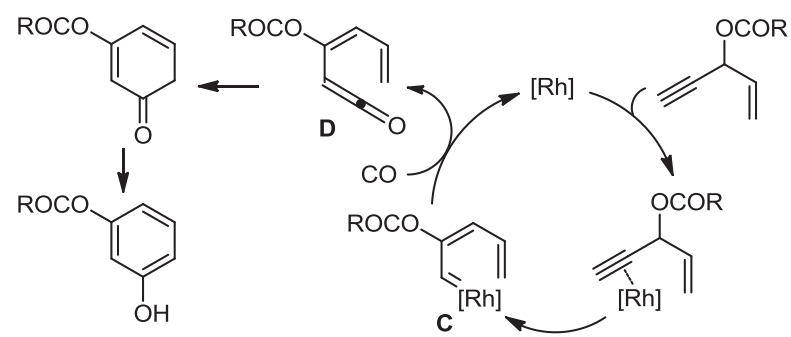

Scheme 1 Proposed mechanism of the $[5+1]$ cycloaddition.

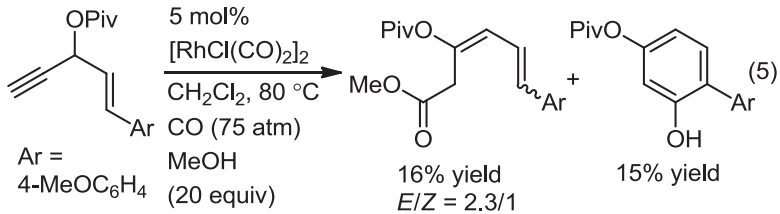

を報告している5)。この反応では，エステル基のアルキ ンへの求核攻撃によって生じたビニルメタル種 Eが, カルベン種 $F$ を経て，または直接，メタラシクロへキ サジエン種 $\mathrm{G}$ へ変換され，Gのロジウムに配位したア ルキンを捕捉することで，縮環した 7 員環を与えると考 えられている。このメタラシクロヘキサジエン種 Gの 生成過程と同様の機構は, パラジウム触媒系による3アシロキシ-1,4-エンインのシクロペンタジエン誘導体 への変換反応に関して, Rautenstrauchによって提唱さ れている $\left(\right.$ スキーム2) ${ }^{6)}$ 。

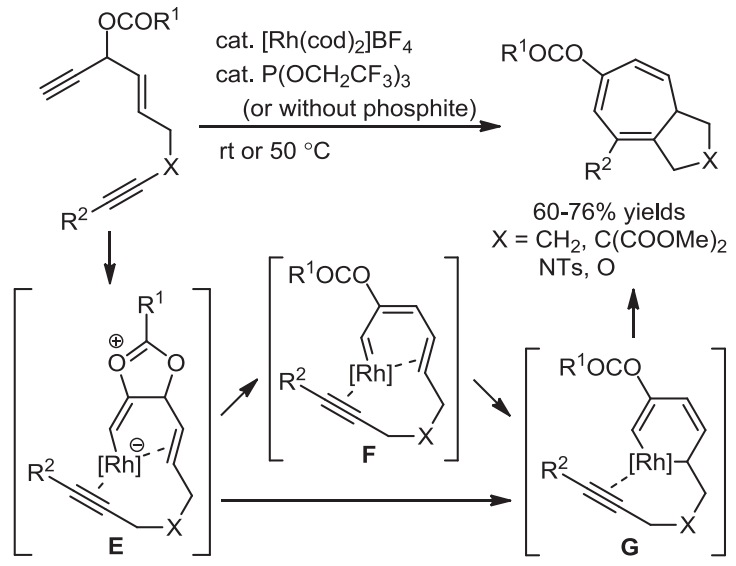

Scheme 2 Proposed mechanism of the intramolecular $[5+2]$ cycloaddition

また, Tangらは, トリアリールホスフィンが配位し たロジウム触媒で，3-アシロキシ-1,4-エンインとアル キンの分子間反応による $[5+2]$ 環化付加体の合成も達成 している ${ }^{5 b)}$ 。エンインと末端アルキン $\left(\mathrm{R}^{4}=\mathrm{H}\right)$ の反応で は, メタラシクロヘキサジエン種へのアルキン挿入の向 き $(\mathrm{H}$ or I I)により，2 種類の異性体が生成するが，アル キン由来の置換基を，アシロキシ基からより遠い位置に もつ異性体が主生成物として得られる。この位置選択性 は, アルキンがメタラシクロヘキサジエン種の $\mathrm{sp}^{2}$ 炭 素-金属結合に挿入する際に，炭素-炭素結合生成部位
での立体障害を避けるように進行するためであると考え られている(スキーム3)。また，ロジウムへの配位が可 能なプロパルギル，またはホモプロパルギル位にへテロ 原子を有するアルキン類では, 特に高位置選択的に目的 の 7 員環化合物が得られる。

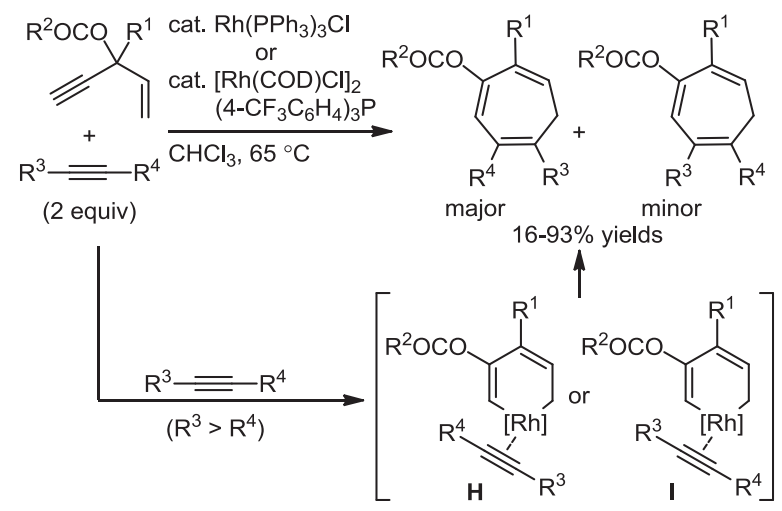

Scheme 3 Proposed mechanism of the intermolecular $[5+2]$ cycloaddition.

\section{おわりに}

プロパルギルエステルの 1,2-アシロキシ転位を経る反 応に関して, ロジウム触媒を用いて最近開発された不飽 和化合物を取り込む反応について紹介した。今後は他の 不飽和化合物との反応に加え, 不斉反応などへの展開が 期待される。

文 献

1) (a)K. Miki, S. Uemura, K. Ohe, Chem. Lett., 34, 1068(2005); (b) J. Marco-Contelles, E. Soriano, Chem. Eur. J., 13, 1350 (2007); (c)K. Ohe, K. Miki, J. Synth. Org. Chem., Jpn., 67, 1161(2009)

2) N. Marison, S. P. Nolan, Angew. Chem. Int. Ed., 46, 2750 (2007)

3) Y. Shibata, K. Noguchi, K. Tanaka, J. Am. Chem. Soc., 132, $7896(2010)$

4) (a) C. Brancour, T. Fukuyama, Y. Ohta, I. Ryu, A.-L. Dhimane, L. Fensterbank, M. Malacria, Chem. Commun., 46, 5470 (2010); (b) T. Fukuyama, Y. Ohta, C. Brancour, K. Miyagawa, I. Ryu, A.-L. Dhimane, L. Fensterbank, M. Malacria, Chem. Eur. J., 18, $7243(2012)$

5) (a) X.-Z. Shu, S. Huang, D. Shu, S. I. Guzei, W. Tang, Angew. Chem. Int. Ed., 50, 8153(2011); (b)X.-Z. Shu, X. Li, D. Shu, S. Huang, C. M. Schienebeck, X. Xhou, P. J. Robichaux, W. Tang, J. Am. Chem. Soc., 134, 5211(2012)

6) V. Rautenstrauch, J. Org. Chem., 49, 950 (1984)

(2012 年 5 月 25 日受理)

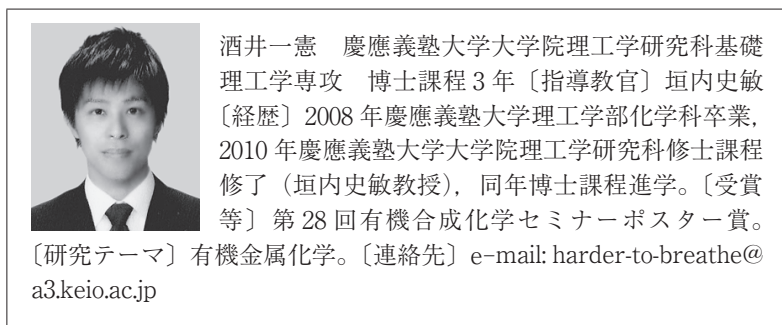

